\title{
Argument Against Our Temporal Agoraphobia
}

For Virgil, history's slope was not a given, as for us who drearily assume

a singular, closed past, matched to a future careeningly wide open. We dream

infinities of choice, beginning now and spreading out into our own remaining spans

as easily as we might (and have, for better or for worse), set off for lands

uncharted (proposing only out of here), worlds woven of the possible and im-

(cloven humans, heads beneath their shoulders; unicorns; lizards born of mud). For him,

a man deferring philosophy for the long years after art, and dying at the seam

where the two might profitably have met, both Past and Future posed their open

questions. The argument came to this: either memory and history (i.e., the chartered

past) can equally ignore the banks, slip the borders, and spread, flood-smeared

over a vast, featureless landscape, all its familiar landmarks hidden

by the waves of our multi-directional wakes, or the future, too, is fixed and bidden

by gods. Which? Logic's a thing you can't have both ways: symmetry requires

the single fulcrum and the stance-which, we're told, is all a man can claim as his 
and all he needs. Two worlds to move in the here-and-now: time to abandon

60 as Dante did, even a half-life's certainty. Ascending our treacherous mountain

peering only up, how can we claim a knowledge - declare a single, reliable fact -

concerning our craven, encumbered selves or the cloven historians at our backs. 